\title{
EFFECT OF DIFFERENT RATES AND FORMS OF SULPHUR ON CONTENT OF AVAILABLE PHOSPHORUS IN SOIL
}

\author{
Małgorzata Skwierawska, Lucyna Zawartka \\ Chair of Agricultural Chemistry and Environmental Protection \\ University of Warmia and Mazury in Olsztyn
}

\begin{abstract}
A three-year field experiment was conducted in Byszwałd near Lubawa in 2000-2002. The aim of this study has been to determine the influence of increasing rates of sulphur on the dynamics of available phosphorus in soil at two horizons: $0-40$ and $40-80 \mathrm{~cm}$. The trial was set up on acid brown soil of the granulometric composition of heavy loamy sand. The initial soil had the following properties: $\mathrm{pH}_{(\mathrm{KCl})}=5.30$, mineral nitrogen 24.0, sulphate sulphur 4.10, available phosphorus 34.5 and potassium $110.0 \mathrm{mg} \mathrm{kg}^{-1}$ of soil.

Three levels of sulphur fertilization were applied: 40,80 and $120 \mathrm{~kg} \cdot \mathrm{ha}^{-1}$ in the sulphate form $\left(\mathrm{S}-S O_{4}\right)$ and as elementary sulphur $\left(\mathrm{S}-\mathrm{S}^{0}\right)$. During the whole duration of the field trials, the results demonstrating the effect of fertilization with different forms and rates of sulphur on the content and transfer of available phosphorus in soil were inconsistent. Only the dose of $120 \mathrm{~kg} \cdot \mathrm{ha}^{-1} \mathrm{~S}_{-} \mathrm{SO}_{4}$ caused a significant increase in the concentration of available sulphur in soil in the 0-40 and 40-80 cm layers. All the rates of elementary sulphur as well as 40 and $80 \mathrm{~kg} \cdot \mathrm{ha}^{-1}$ sulphate sulphur caused little less but an increasing tendency in the content of phosphorus in soil. The effect of elementary sulphur became apparent as late as the third year of the trials. The effect of the doses of 40 and $80 \mathrm{~kg} \cdot \mathrm{ha}^{-1}$ of sulphur on properties of soil depended on the form of sulphur, duration of the experiment.
\end{abstract}

Key words: fertilization, sulphate sulphur, elementary sulphur, available phosphorus, soil.

dr inż. Małgorzata Skwierawska, Chair of Agricultural Chemistry and Environmental Protection, University of Warmia and Mazury, ul. Oczapowskiego 8, 10-718 Olsztyn, Poland 


\title{
WPŁYW RÓŻNYCH DAWEK I FORM SIARKI NA ZAWARTOŚĆ PRZYSWAJALNEGO FOSFORU W GLEBIE
}

\begin{abstract}
Abstrakt
W latach 2000-2002, w Byszwałdzie, w pobliżu Lubawy, przeprowadzono 3-letnie doświadczenie polowe. W doświadczeniu badano wpływ nawożenia siarką na dynamikę przyswajalnego fosforu $\mathrm{w}$ glebie $\mathrm{w}$ dwóch poziomach: 0-40 cm i 40-80 cm. Eksperyment założono na glebie brunatnej, kwaśnej o składzie granulometrycznym piasku gliniastego mocnego. Gleba wyjściowa miała nstępujące właściwości: $\mathrm{pH}_{(\mathrm{KCl})}=5,30$, azot mineralny 24,0 , siarka siarczanowa 4,10 , przyswajalny fosfor 34,5 , potas $110,0 \mathrm{mg} \cdot \mathrm{kg}^{-1}$ gleby. Zastosowano 3 poziomy nawożenia siarka: 40,80 i $120 \mathrm{~kg} \cdot \mathrm{ha}^{-1} \mathrm{w}$ formie siarczanowej $\left(\mathrm{S}_{-} \mathrm{SO}_{4}\right)$ i elementarnej $\left(\mathrm{S}_{-} \mathrm{S}^{0}\right)$. W ciagu całego okresu badań otrzymano niejednoznaczne wyniki dotyczące wpływu nawożenia różnymi formami i dawkami siarki na zawartość i przemieszczanie się przyswajalnego fosforu w glebie. Jedynie dawka $120 \mathrm{~kg} \cdot \mathrm{ha}^{-1} \mathrm{~S}^{-\mathrm{SO}_{4}}$ przez cały okres badań wpływała na uruchamianie i migrację fosforu glebie oraz spowodowała istotne zwiększenie zawartości przyswajalnego fosforu $\mathrm{w}$ glebie $\mathrm{w}$ warstwie $0-40 \mathrm{~cm}$ i $40-80 \mathrm{~cm}$. Wszystkie dawki siarki elementarnej oraz 40 i $80 \mathrm{~kg}$ siarki siarczanowej powodowały jedynie tendencję zwyżkowa. Wpływ siarki elementarnej uwidocznił się dopiero w trzecim roku doświadczenia. Działanie dawek 40 i $80 \mathrm{~kg} \cdot \mathrm{ha}^{-1}$ siarki na właściwości gleby zależało od formy siarki oraz czasu trwania doświadczenia.
\end{abstract}

Słowa kluczowe: nawożenie, siarka siarczanowa, siarka elementarna, przyswajalny fosfor, gleba.

\section{INTRODUCTION}

Sulphur deficit in Europe becomes evident not only in high sulphur demanding crops but has already become a problem for farmers growing cereals (Schung et al. 1993, ZHAO et al 1996, Scherer 2001). At present, there is a growing interest in sulphur as a component of fertilisers, especially in non-industrialised areas situated far from large cities, where deficient quantities of sulphur in plants are detected (KACZOR and BRODOwsKA 2002). Phosphorus metabolism in soil is important for both agriculture and environment as different forms and levels of phosphorus play a decisive role in plant production and eutrophication of water bodies (SHARPLEY 1995). The results of studies on the effect of sulphur on fluctuations in concentrations of available sulphur in soil are inconsistent. MoTOWICKA-TERELAK and TERELAK (1998) demonstrated that sulphur, by binding aluminium sulphate, reduced phosphorus fixation in soil, while excessive amounts of sulphates may result in incomplete utilization of phosphorus supplied with fertilizers, as they inhibit the growth of crops. In contrast, LINDEMANN et al. (1991) did not determine such a relationship. In soils fertilized with elementary sulphur, access of plants to available sulphur is improved (JAGGI et al. 2005).

The purpose of the present study has been to determine the effect of fertilization with increasing rates of sulphur applied in the form of sulphates and as elementary sulphur on the content of available phosphorus forms in soil the 0-40 and 40-80 cm layers. 


\section{MATERIAL AND METHODS}

A three-year field experiment was conducted from 2000 to 2002 , in Byszwałd near Lubawa. The village is distant from larger industrial plants which emit sulphur compounds and lies far from any big cities. As a result, any changes in the concentration of sulphur in the soil were not caused by human pressure.

The trial was set up on acid brown soil of the granulometric composition of heavy loamy sand. The initial soil had the following properties: $\mathrm{pH}_{(\mathrm{KCl})}=5.30$, mineral nitrogen 24.0, sulphate sulphur 4.10, available phosphorus 34.5 and potassium $110.0 \mathrm{mg} \mathrm{kg}^{-1}$ of soil. The annual rates of sulphate sulphur $\left(\mathrm{S}_{-} \mathrm{SO}_{4}\right)$ and elementary sulphur $\left(\mathrm{S}_{-} \mathrm{S}^{0}\right)$ were: $\mathrm{S}_{1}-40, \mathrm{~S}_{2}-80$ and $\mathrm{S}_{3}-120 \mathrm{~kg} \mathrm{ha}^{-1}$.

The permanent experiment was established in a random block design and consisted of eight fertilisation objects with four replications: 1) 0,2) $\left.\left.\left.\mathrm{NPK}, 3) \mathrm{NPK}+\mathrm{S}_{1}-\mathrm{SO}_{4}, 4\right) \mathrm{NPK}+\mathrm{S}_{2}-\mathrm{SO}_{4}, 5\right) \mathrm{NPK}+\mathrm{S}_{3}-\mathrm{SO}_{4}, 6\right) \mathrm{NPK}+\mathrm{S}_{1}-\mathrm{S}^{0}$, 7) $\left.\mathrm{NPK}+\mathrm{S}_{2}-\mathrm{S}^{0}, 8\right) \mathrm{NPK}+\mathrm{S}_{3}-\mathrm{S}^{0}$. The NPK rates depended on the crop species and soil fertility (Table 1). The design of the experiment is presented in Tables 2-4. The following fertilisers were applied: nitrogen - ammonium nitrate or ammonium sulphate, phosphorus - triple superphosphate, potassium - potassium chloride $60 \%$ or potassium sulphate, sulphur - potassium sulphate and, as a supplement, ammonium sulphate; in addition, elementary sulphur was applied on the objects where this form of sulphur was tested.

NPK rates applied in the trials

\begin{tabular}{|l|c|c|c|c|}
\hline \multirow{2}{*}{ Crops } & \multirow{2}{*}{ Year } & \multicolumn{3}{|c|}{$\left(\mathrm{kg} \cdot \mathrm{ha}{ }^{-1}\right)$} \\
\cline { 3 - 5 } & & $\mathrm{N}$ & $\mathrm{P}$ & $\mathrm{K}$ \\
\hline Head cabbage & 2000 & 200.0 & 52.5 & 180.0 \\
\hline Common onion & 2001 & 160.0 & 60.0 & 183.0 \\
\hline Spring barley & 2002 & 90.0 & 80.0 & 111.0 \\
\hline
\end{tabular}

Soil samples were collected from each plot, at 0-40 and 40-80 cm depths, prior to the establishment of the trials, after each harvest and before sowing the consecutive crop. There was one exception to the routine - in spring 2001 , due to prolonged rains, soil samples were taken only from the $0-40 \mathrm{~cm}$ horizon. Available phosphorus was determined with Enger Riehm's method (DL) (the ratio between soil and extraction 1:50).

The concentrations of available phosphorus in soil were processed statistically using analysis of variance for two-factor experiments in a randomblock design, assuming the form of sulphur as factor a and rate of sulphur 
Table 2

Effect of different rates and forms of sulphur on the content of available phosphorus in soil at $0-40 \mathrm{~cm}$ depth $\left(\mathrm{mg} \cdot \mathrm{kg}^{-1}\right.$ soil $)$

\begin{tabular}{|c|c|c|c|c|c|}
\hline \multirow{2}{*}{ Treatments } & $\begin{array}{c}2000 \\
\text { autumn }\end{array}$ & $\begin{array}{c}2001 \\
\text { spring }\end{array}$ & $\begin{array}{c}2001 \\
\text { autumn }\end{array}$ & $\begin{array}{c}2002 \\
\text { spring }\end{array}$ & $\begin{array}{c}2002 \\
\text { autumn }\end{array}$ \\
\hline & \multicolumn{5}{|c|}{ soil at $0-40 \mathrm{~cm}$ depth } \\
\hline 0 & 34.8 & 34.1 & 57.0 & 44.1 & 27.4 \\
\hline NPK & 41.0 & 31.6 & 53.1 & 41.0 & 37.5 \\
\hline $\mathrm{NPK}+\mathrm{S}_{1}-\mathrm{SO}_{4}$ & 50.1 & 38.6 & 91.3 & 43.8 & 47.7 \\
\hline $\mathrm{NPK}+\mathrm{S}_{2}-\mathrm{SO}_{4}$ & 45.2 & 32.1 & 68.0 & 38.5 & 40.3 \\
\hline $\mathrm{NPK}+\mathrm{S}_{3}-\mathrm{SO}_{4}$ & 35.6 & 33.5 & 91.3 & 43.4 & 49.2 \\
\hline $\mathrm{NPK}+\mathrm{S}_{1}-\mathrm{S}^{0}$ & 39.7 & 33.5 & 55.3 & 35.1 & 38.0 \\
\hline $\mathrm{NPK}+\mathrm{S}_{2}-\mathrm{S}^{0}$ & 48.6 & 33.2 & 56.0 & 35.4 & 39.3 \\
\hline $\mathrm{NPK}+\mathrm{S}_{3}-\mathrm{S}^{0}$ & 45.1 & 33.6 & 66.4 & 42.4 & 44.7 \\
\hline $\begin{array}{l}\text { NIR- } p-0.05 \\
a \\
b \\
a \times b\end{array}$ & $\begin{array}{l}\text { n.s.* } \\
2.44 \\
\text { n.s. }\end{array}$ & $\begin{array}{l}\text { n.s. } \\
\text { n.s. } \\
\text { n.s. }\end{array}$ & $\begin{array}{l}\text { n.s. } \\
1.68 \\
2.38\end{array}$ & $\begin{array}{l}2.25 \\
3.19 \\
4.51\end{array}$ & $\begin{array}{l}1.64 \\
2.32 \\
3.29\end{array}$ \\
\hline
\end{tabular}

$\mathrm{SO}_{4}$ - sulphate sulphur; $\mathrm{S}^{0}$ - elementary sulphur; $\mathrm{S}_{1}-40 \mathrm{~kg} \cdot \mathrm{ha}^{-1}, \mathrm{~S}_{2}-80 \mathrm{~kg} \cdot \mathrm{ha}^{-1}$,

$\mathrm{S}_{3}-120 \mathrm{~kg} \cdot \mathrm{ha}^{-1}$

$a$ - form of sulphur; $b$ - dose of sulphur; $a \times b$-interaction

* n.s. - non-significant difference

as factor b. Additional statistical analyses were performed with the software package Statistica 6.0 PL, to carry out analysis of regression with Duncan's tests in order to determine statistical differences between sets of data.

\section{DISCUSSION OF THE RESULTS}

In 2000 , the amount of available phosphorus in the $0-40 \mathrm{~cm}$ soil layer was varied, ranging between 34.8 and $50.1 \mathrm{mg} \mathrm{P} \cdot \mathrm{kg}^{-1}$ of soil (Table 2). NPK as well as NPK+S fertilization caused significant increase in the concentration of available phosphorus versus the control and initial soil. When a single rate of sulphate sulphur was applied, the concentration of available phosphorus in soil increased versus the NPK fertilized object. The application of $120 \mathrm{~kg} \cdot \mathrm{ha}^{-1} \mathrm{~S}_{-} \mathrm{SO}_{4}$ caused a significant decline in the amount of available phosphorus in soil relative all the remaining fertilization objects. This decrease could have been due to several factors, for example transfer of phosphorus to the deeper soil layer $40-80 \mathrm{~cm}$ (Table 3). In the $40-80 \mathrm{~cm}$ soil horizon, the other sulphur rates had little effect on the dynamics of available phosphorus. As the rates of sulphate sulphur applied as a fertilizer rose, 
Table 3

Effect of different rates and forms of sulphur on the content of available phosphorus in soil at $40-80 \mathrm{~cm}$ depth $\left(\mathrm{mg} \mathrm{kg}^{-1}\right.$ soil)

\begin{tabular}{|c|c|c|c|c|c|}
\hline \multirow[t]{2}{*}{ Treatments } & $\begin{array}{c}2000 \\
\text { autumn }\end{array}$ & $\begin{array}{c}2001 \\
\text { spring }\end{array}$ & $\begin{array}{c}2001 \\
\text { autumn }\end{array}$ & $\begin{array}{c}2002 \\
\text { spring }\end{array}$ & $\begin{array}{c}2002 \\
\text { autumn }\end{array}$ \\
\hline & \multicolumn{5}{|c|}{ soil at $40-80 \mathrm{~cm}$ depth } \\
\hline 0 & 36.2 & - & 36.2 & 36.2 & 36.7 \\
\hline NPK & 33.0 & - & 33.0 & 33.0 & 32.4 \\
\hline $\mathrm{NPK}+\mathrm{S}_{1}-\mathrm{SO}_{4}$ & 34.3 & - & 34.3 & 34.3 & 28.3 \\
\hline $\mathrm{NPK}+\mathrm{S}_{2}-\mathrm{SO}_{4}$ & 29.0 & - & 29.0 & 29.0 & 22.0 \\
\hline $\mathrm{NPK}+\mathrm{S}_{3}-\mathrm{SO}_{4}$ & 37.6 & - & 37.6 & 37.6 & 49.9 \\
\hline $\mathrm{NPK}+\mathrm{S}_{1}-\mathrm{S}^{0}$ & 33.5 & - & 33.5 & 33.5 & 32.2 \\
\hline $\mathrm{NPK}+\mathrm{S}_{2}-\mathrm{S}^{0}$ & 35.7 & - & 35.7 & 35.7 & 35.1 \\
\hline $\mathrm{NPK}+\mathrm{S}_{3}-\mathrm{S}^{0}$ & 33.8 & - & 33.8 & 33.8 & 41.3 \\
\hline $\begin{array}{l}\text { NIR-p-0.05 } \\
\mathrm{a} \\
b \\
a \times b\end{array}$ & $\begin{array}{l}1.48 \\
2.09 \\
* \text { n.s. }\end{array}$ & - & $\begin{array}{c}1.48 \\
2.09 \\
\text { n.s. }\end{array}$ & $\begin{array}{c}1.48 \\
2.09 \\
\text { n.s. }\end{array}$ & $\begin{array}{l}2.25 \\
3.18 \\
4.50\end{array}$ \\
\hline
\end{tabular}

$\mathrm{SO}_{4}$ - sulphate sulphur; $\mathrm{S}^{0}$ - elementary sulphur; $\mathrm{S}_{1}-40 \mathrm{~kg} \cdot \mathrm{ha}^{-1}, \mathrm{~S}_{2}-80 \mathrm{~kg} \cdot \mathrm{ha}^{-1}$,

$\mathrm{S}_{3}-120 \mathrm{~kg} \cdot \mathrm{ha}^{-1}$

$a$ - form of sulphur; $b$ - dose of sulphur; $a \times b$ - interaction

$*$ n.s. - non-significant difference

a tendency towards decreasing concentration of available phosphorus in soil appeared. However, the application of elementary sulphur resulted in less regular changes.

In the second year of the experiment (2001), the concentration of available phosphorus in the $0-40 \mathrm{~cm}$ soil layer was uniform and independent of the sulphur fertilization (Table 2).

In autumn (2001), the level of phosphorus in soil was evidently higher in all the objects fertilized with sulphur than in the NPK fertilized object, especially after all the increasing rates of sulphate sulphur as well as a triple dose of elementary sulphur had been applied. It is most likely that the process of elementary sulphur oxidation was initiated or else increasing rates of $\mathrm{S}_{-} \mathrm{SO}_{4}$ were observed to be followed by a decreasing uptake of phosphorus by onion plants Skwierawska et al (2008). In the $40-80 \mathrm{~cm}$ soil layer, sulphur fertilization had an ambiguous influence on the amount of available phosphorus. This form of phosphorus occurred in increased quantities in the objects which had received $120 \mathrm{~kg} \cdot \mathrm{ha}^{-1}{\mathrm{~S}-\mathrm{SO}_{4}}_{4}$ and $80 \mathrm{~kg} \cdot \mathrm{ha}^{-1} \mathrm{~S}_{-} \mathrm{S}^{0}$ (Table 3). Other authors, e.g. KRóL et al. (1986), МотоwICKA-TERELAK (1989), JAGGi et al. (2005) have also noticed that the content of available phosphorus in soil under the influence of sulphur tends to increase. The sulphur fertilization applied in the second year of the experiment increased the amounts of avail- 
Table 4

Significance of differences in the content of available phosphorus in soil between particular objects according to Duncan's test.

Differences statistically significant at $(p \leq 0.05)$

\begin{tabular}{|l|c|c|c|c|c|c|c|c|}
\hline Object & 0 & $\mathrm{NPK}$ & $\mathrm{I}_{-S-S O}$ & II-S-SO $_{4}$ & III-S-SO $_{4}$ & I-S-S $^{0}$ & II-S-S $^{0}$ & III-S-S $^{0}$ \\
\hline 0 & & & & & & & & \\
\hline $\mathrm{NPK}_{1} 0.400789$ & & & & & & & \\
\hline $\mathrm{S}_{2}-\mathrm{SO}_{4}$ & 0.002371 & 0.025297 & & & & & & \\
\hline $\mathrm{S}_{3}-\mathrm{SO}_{4}$ & 0.000667 & 0.010226 & 0.697388 & 0.000779 & & & & \\
\hline $\mathrm{S}_{1}-\mathrm{S}^{0}$ & 0.772696 & 0.285048 & 0.000969 & 0.733427 & 0.000241 & & & \\
\hline $\mathrm{S}_{2}-\mathrm{S}^{0}$ & 0.192724 & 0.588087 & 0.075883 & 0.200051 & 0.036888 & 0.125709 & & \\
\hline $\mathrm{S}_{3}-\mathrm{S}^{0}$ & 0.071181 & 0.293166 & 0.195560 & 0.075410 & 0.112098 & 0.041239 & 0.561581 & \\
\hline $\bar{x}^{*}$ & 3.578 & 3.798 & 4.392 & 3.597 & 4.487 & 3.507 & 3.931 & 4.074 \\
\hline
\end{tabular}

$* \bar{x}$ - average content of available phosphorus in soil in particular objects for the years 2000-2003 (mg $\cdot \mathrm{kg}^{-1}$ soil); $\mathrm{SO}_{4}$ - sulphate sulphur, $\mathrm{S}^{0}$ - elementary sulphur, $\mathrm{S}_{1}-40 \mathrm{~kg} \mathrm{ha}^{-1}$, $\mathrm{S}_{2}-80 \mathrm{~kg} \mathrm{ha}{ }^{-1}, \mathrm{~S}_{3}-120 \mathrm{~kg} \cdot \mathrm{ha}^{-1}$

able phosphorus in soil at the depths of $0-40 \mathrm{~cm}$ and $40-80 \mathrm{~cm}$ compared to the results obtained during the first year of the trials.

In the spring of 2002, the content of available phosphorus in soil sampled at $0-40 \mathrm{~cm}$ and $40-80 \mathrm{~cm}$ depth was smaller than in autumn 2001 (Tables 2,3 ), and ranged 29.0 and $44.1 \mathrm{mg} \mathrm{P} \cdot \mathrm{kg}^{-1}$ of soil.

In the autumn of 2002, all the fertilization rates of sulphate sulphur and elementary sulphur caused an increase in the amount of available phosphorus in soil sampled at $0-40 \mathrm{~cm}$ depth, which was particularly high after the triple sulphate sulphur dose. The increase was observed versus the control objects (Table 2). The fertilization with sulphate and elementary sulphur increased the concentration of available phosphorus in the $0-40 \mathrm{~cm}$ soil layer compared to the soil tested in spring, whereas the objects fertilized without sulphur became less abundant in phosphorus. At the soil depth of 40-80 $\mathrm{cm}$, the concentration of available phosphorus decreased following the application of 40 and $80 \mathrm{~kg} \cdot \mathrm{ha}^{-1}$ of either sulphur form. It was only when $120 \mathrm{~kg} \cdot \mathrm{ha}^{-1}$ of $\mathrm{S}^{-\mathrm{SO}_{4}}$ or $\mathrm{S}^{-\mathrm{S}^{0}}$ was used that the soil was enriched with available phosphorus, which was also demonstrated in the earlier years of the trials. 
During the whole duration of the field trials, the results demonstrating the effect of fertilization with different forms and rates of sulphur on the content and transfer of available phosphorus in soil were inconsistent. Only one rate of phosphorus, $120 \mathrm{~kg} \cdot \mathrm{ha}^{-1} \mathrm{~S}_{-} \mathrm{SO}_{4}$ initiated mobilization and migration of phosphorus in soil throughout the whole period of the field trails.

The effect produced by elementary sulphur depended on the rate of its oxygenation in soil and its dose, which finds confirmation in studies reported by Germid and JANZEN (1993) as well as WATKInson and LeE (1994) and ZHOU (2002). This is proven by that fact that the concentration of available phosphorus in soil increased as late as the third year of our experiment and only in the object fertilized with $120 \mathrm{~kg} \cdot \mathrm{ha}^{-1} \mathrm{~S}-\mathrm{S}^{0}$. LINDEMANN et al. (1991) did not find any increase in available phosphorus in soil following fertilization treatments with elementary sulphur, even though the soil $\mathrm{pH}$ was lowered and the amount of the sulphate form in soil increased. According to JAGII et al. (2005), addition of elementary sulphur improves the availability of phosphorus in cultivated soils, irrespective of the soil initial $\mathrm{pH}$.

The available references contain diverse interpretation of the influence of sulphur on the dynamics of available phosphorus in soil. The differences stem from changes in soil $\mathrm{pH}$, competition among sulphate ions, mineralization of phosphorus organic forms (JAGGI et al. 1999, 2005) as well as liberation of aluminium and iron ions, which by reacting with sulphates bind fewer phosphate ions. Besides, the presence of free sulphur acid in sulphur-rich soils creates favourable conditions for the release of phosphorus from compounds which are hardly soluble (GADOR, MOTOWICKA-TERELAK 1986b). According to KACZOR (1996), application sulphur acid during three years cause decreasing concentration of available phosphorus in soil.

The computation of the level of significance of the differences performed with Duncan's test (Table 4) showed statistically significant differences between particular objects during the three years of the experiment. The object fertilized with the triple dose of sulphate sulphur was the most distinct one as the average content of available phosphorus determined in its soil was the highest and significantly different from the values established in the other fertilization objects.

\section{CONCLUSIONS}

1. The application of $120 \mathrm{~kg} \cdot \mathrm{ha}^{-1}$ of $\mathrm{S}_{-} \mathrm{SO}_{4}$ caused significant increase in the content of available phosphorus in soil in the layers at 0-40 and 40$-80 \mathrm{~cm}$ depth. All rates of elementary sulphur as well as those of 40 and $80 \mathrm{~kg} \cdot \mathrm{ha}^{-1}$ of sulphate sulphur produced only an increasing tendency in the soil concentration of phosphorus. 
2. The effect of elementary sulphur on mobilization of phosphorus in soil revealed itself as late as the third year of the experiment.

3 . The effect of the doses of 40 and $80 \mathrm{~kg} \cdot \mathrm{ha}^{-1}$ of sulphur on properties of soil depended on the form of sulphur, duration of the experiment.

\section{REFERENCES}

Gądor J., Motowicka-Terelak T. 1986b. Wptyw zasiarczenia gleb na ich właściwości oraz na plonowanie roślin $w$ doświadczeniu lizymetrycznym. Cz. II. Wpływ zasiarczania gleb siarka elementarna na plonowanie i sktad chemiczny roślin uprawnych [Effect of high sulphur content in soils on soil properties and crop yield in a lysimetric experiment. Part II. Effect of introducing elemntary sulphur to soil on yield and chemical composition of crops]. Pam. Puł., 88: 25-37. (in Polish)

GERmida J.J, JANZEN H.H. 1993. Factors affecting the oxidation of elemental sulphur in soils. Fer. Res., 35: 101-114.

Jaggi R.C., Aulakh M.S., Sharma R. 1999. Temperature effects on soil organic sulphur mineralization and elemental sulphur oxidation in subtropical soils of varying $p H$. Nutr. Cycl. Agroecosys., 54: 175-182.

JAGGi R.C., Aulakh M.S., Sharma R. 2005. Impacts of elemental $S$ applied under various temperature and moisture regimes on $p H$ and available $P$ in acidic, neutral and alkaline soils. Biol. Fertil. Soils, 41: 52-58.

KACZOR A. 1996. Działanie następcze stymulowanych kwaśnych opadów i dolomitu na plonowanie kupkówki pospolitej oraz na zawartość $w$ glebie przyswajalnych form fosforu, potasu $i$ magnezu \{Carryover effect of stimulated acid rains and dolomite on common cocksfoot yield and soil content of available forms of phosphorus, potassium and magnesium]. Rocz. Glebozn., 47(3/4): 223-229. (in Polish)

Kaczor A., Brodowska M. 2002. Wptyw wapnowania i nawożenia siarka na zawartość azotu mineralnego $w$ jarych formach pszenicy $i$ rzepaku [Effect of liming and sulphur feretilization on content of mineral nitrogen in spring forms of wheat and oilseed rape]. Zesz. Probl. Post. Nauk Rol., 484: 237-242. (in Polish)

Król M., Kobus J., MaziarczyK B. 1986. Zmiany biologiczne i chemiczne zachodzqce w różnych glebach pod wptywem stosowania siarki elementarnej [Biological and chemical changes occurring in different soils under the influence of elementary sulphur application]. Pam. Puł., 88: 39-55. (in Polish)

Lindemann W. C., Aвurto J. J., Haffner W. M., Bono A.A. 1991. Effect of sulfur source on sulfur oxidation. Soil Sci. Soc. Am. J., 55(1): 85-90.

Motowicka-Terelak T. 1989. Badania modelowe nad mechanizmami $i$ skutkami degradacji gleb zanieczyszczonych zwiazkami siarki. Cz. I. Zmiany wtaściwości chemicznych gleby gliniastej $w$ warunkach systematycznego zasiarczania [Model studies on mechanisms and results of degradation of soils polluted with sulphur compounds. Part I. Changes in the chemical properties of loamy soil under regular sulphur ocntamination]. Pam. Puł., 94: 11-28. (in Polish)

Motowicka-Terelak T.,Terelak H. 1998. Siarka $w$ glebach Polski. Stan i zagrożenie [Sulphur in Polish soils. The current state and thread]. PIOŚ, Bibl. Monit. Srod., Warszawa, 1-106. (in Polish)

SCHERER H.W., 2001. Sulphur in crop production invited paper. Eur. J. Agron., 14:88-111.

Schung E., Haneklaus S., Murphy D. 1993. Impact of sulphur on the baking quality of wheat. Asp. Appl. Biol. 36, Cereal Qual., 3: 337-345.

Sharpley A.N. 1995. Soil phosphorus dynamics: agronomic and environomental impacts. Ecol. Eng., 5: 261-279. 
Skwierawska M., Zawartka L., Zawadzki B. 2008. The effect of different rates and forms of applied sulphur on nutrient composition of planted crops. Plant Soil Environ., 54: 179-189.

WatKinson, Lee. 1994. Kinetics if field oxidation of elemental sulfur in New Zealand pastoral soils and the effects of soil temperature and moisture. Fertil. Res., 37: 59-68.

Zhao F.J., Hawkesford M.J., Warrilow A. G. S., McGrath S.P., Clarkson D.T., 1996. Responses of two wheat varieties to sulphur addition and diagnosis of sulphur dificiency. Plant Soil, 81: 317-327.

Zhou W., Wan M., He P., Li S., Lin B. 2002. Oxidation of elemental sulphur in paddy soils as influenced by flooded condition and plant growth in pot experiment. Biol. Fertil. Soils, 36: 384-389. 
